five on four separate days. The most intense activity, however, seems to have been near Silchar on May 27, 1939, when eight shocks were felt attaining a maximum intensity seven on the Rossi-Forel scale (overturning of loose objects ; fall of plaster ; general fright, though no damage to property). The total duration of shaking was approximately $3 \frac{1}{2}$ minutes.

\section{Undulant Fever in Normandy}

IN his inaugural thesis (Thèse de Paris, 1940, No. 322), Dr. M. L. Rose-Legrand remarks that until the last few years the five departments of Normandy were regarded as free from human undulant fever. Recent publications, however, indicate that Normandy has by no means escaped visitations of this disease, as is shown by the fact that the writer has been able to collect at least twenty-seven cases in the course of the last six years, eleven being in SeineInférieure, six in Calvados, five in Eure, three in Manche and one in Orne. With the exception of a single case caused by $B$. melitensis, all the cases of human undulant fever have resulted from infection by $B$. abortus bovis. Not a single case in the departments of Normandy has been due to goats or sheep. In two instances infection was caused by accidental inoculation, namely, by a polyvalent vaccine in a veterinary surgeon, and in another in a cattle breeder. In the majority of cases inoculation has taken place through the skin and only in a minority by consump. tion of raw milk from infected cows. Hitherto, there have been no instances of human infection by cheese. In conclusion, the writer recommends that the wellestablished existence of undulant fever in Normandy should receive the attention of veterinary and medical practitioners, especially in rural districts. In another thesis (Thèse de Paris, 1940, No. 277), Dr. R. G. C. F. Grigny states that he has recently collected ten cases of undulant fever which have occurred during the last four years in the department of the Somme, where contagious abortion has recently been frequent among the cattle.

\section{Carnegie Institution of Washington}

YEAR BooK No. 38 of the Carnegie Institution of Washington has been issued and covers the year July 1, 1938-June 30, 1939. It includes the report of the President, the reports of the various Departments, including the Mount Wilson Observatory, the Geophysical Laboratory, the Department of Terrestrial Magnetism, the Division of Plant Biology, the Division of Animal Biology and the Division of Historical Research, as well as reports on investigations by research associates and on special co-operative studies such as those of the committee on co-ordination of cosmic ray investigations. The astronomical staff at Mount Wilson has continued to co-operate with the physicists and engineers of the Californian Institute of Technology in the construction of the 200-inch telescope with the aid of funds furnished by the Rockefeller Foundation.

The Department of Terrestrial Magnetism, in co-operation with George Washington University, held a conference on theoretical physics in the spring, and keen interest was also taken in a similar conference on the ionosphere. Special reference is made in the report to the work of the Division of Plant Biology on photosynthesis, including studies of the quantum efficiency of photosynthesis. The work of the Division of Animal Biology has included biochemical studies of secretion, the physiology of reproduction, endocrine studies, studies of the central nervous system, as well as investigations on the chromosome and the gene. Research activities in the Nutrition Laboratory have centred largely around the factors governing heat regulation and heat production in animals and human beings.

\section{A Guide to Farming}

THE fifteenth issue of the "Farmer's Guide" has been published in the Journal of the Royal Agricultural Society of England, 101, Part 1. It follows the lines of former issues, but naturally a good deal of the work under review bears on the special problems of war-time farming. The contributors to the various sections are the same as last year, except that Prof. T. Dalling has replaced Dr. F. C. Minett as the writer on animal diseases. In future the Journal will be issued in two parts only, at half-yearly intervals, instead of in three parts as originally planned. So far as can be foreseen at present, Part 2 of the current volume will be published in March 1941.

\section{Announcements}

IN connexion with Dr. R. Melville's letter on p. 403 of this issue, it may be noted that the Board of Education has issued a memorandum suggesting the collection by school children of wool, dandelion roots, autumn crocus roots and seeds, acorns and beech mast, and horse chestnuts.

Dr. Ivor JENNING has been appointed principal of the University College of Ceylon, and Mr. Stanley A. A. Hammond educational adviser on the West Indian Comptroller's staff.

According to Science, Dr. Bruno Gerhard, formerly curator of the Museum of Hygiene in Dresden, has been appointed director of the Cleveland Museum of Health and Hygiene, which will open in October. Since 1937, Dr. Gerhard has been serving as technical consultant for the medicine and public health exhibits at the World's Fair in New York. Plans for the Cleveland Museum were initiated in 1939 when Mrs. Francis F. Prentișs gave the building. In addition to exhibits for education in public health, the museum expects to have workshops for the creation of visual health aids for schools, colleges and other educational institutions.

Dr. Joseph NeenhaM has pointed out that a misprint appears in the title of an article by him in association with Dr. A. S. C. Lawrence and Dr. Shih-Chang Shen in Nature of July 20, p. 104. The full title of the original paper was "Studies on Protein Solutions with the Co-axial (or Couette) Viscosimeter, with reference to the Relations between Molecular and Morphological Shape" ; this would of course have been too cumbersome for an article in NATURE. 